\title{
GYGES AND KANDAULES IN ANCIENT AND MODERN LITERATURE*
}

\section{$B$ van Zyl-Smit (University of the Western Cape)}

The intriguing story of how Gyges came to succeed Kandaules as king of Lydia in 685 B.C. is told as historical fact by Herodotus in Historiae I.8-12. In addition to the account of Herodotus, Plato in Republic $2.359 \mathrm{~d}-360 \mathrm{~b}$ includes the tale of a shepherd called Gyges who finds a ring which renders him invisible and enables him to usurp the throne. This, as will be shown below, refers to the same historical episode and has often been combined with Herodotus' version by later writers. In spite of its kernel of historical veracity, this story has been handled in later literature as if it were mythological. Like many Greek myths it has provided inspiration for later writers in a variety of genres. ${ }^{1}$ It is the purpose of this paper to examine how Jean La Fontaine in seventeenth-century France, Theophile Gautier in nineteenth-century France, Friedrich Hebbel in nineteenth-century Germany, André Gide at the start of the twentieth century in France and Anthony Powell in the second half of the twentieth century in England, have each made use of this story in the creation of a particular work of literature.

In his seminal work Palimpsestes: La littérature au second degré, the French scholar Gérard Genette sets out his theory of 'hypertextualité' (1982:13). This deals with the notion, familiar to classicists, that certain texts are and have been, since the time of the ancient Greeks, constantly reworked by writers in different genres and languages. Genette likens this process to that of the creation of a palimpsest (1982:556). A new text may all but obscure the preceding, but the first layer, and sometimes many others, will still be discernible to a greater or lesser extent. The two Greek texts which have been mentioned above, would be called 'hypotextes' by Genette. By means of 'hypertextualite' which implies the 'imitation' or 'transformation' of the 'hypotexte', the passages concerning the succession of Gyges have appeared in different literatures at different times. Yet, if one reads the later work closely, the original or 'hypotexte' is still evident and is sometimes even ackowledged by the author as a source of inspiration. An example (among many) cited by Genette of such a 'hypotexte' is the Odyssey, with Vergil's Aeneid and James Joyce's Ulysses as two of its many 'hypertextes'. For Genette the special interest of such 'hypertextualite' is the constantly new meaning thus given to the 'hypotexte'. This proposition may be illustrated by an examination of the postclassical treatments of the story of Gyges and Kandaules.

This is a revised and expanded version of a paper given at the CASA conference in Bloemfontein in January 1995. I would like to dedicate it to Prof. Conradie in gratitude for his pioneering work on the influence of Greek drama on later and modern theatre.

1 For discussion of Greek myth as inspiration for later writers, especially dramatists, see Conradie 1963 and 1976; Fuhrmann 1971:121-143; Genette 1982; Highet 1967:520-540; Steiner 1984:300-304. 
In order to understand the manipulation of the two classical 'hypotextes' by later authors it is necessary to discuss these two texts first. It will become clear that sometimes the 'hypertextes' are the product of a 'contamination' of the two Greek versions and that additional material from other sources ('hypotextes' and/or 'hypertextes') has sometimes been incorporated. As Genette (1982:370) remarks, the practice of 'contamination' was well established among the ancients, especially the Roman comic poets.

Herodotus tells the story of Gyges and Kandaules to explain how royal power in Lydia was transferred from the Heraclids to the Mermnads. It is accepted by scholars that it contains a nucleus of historical fact. According to Herodotus (Historiae 1.8-12), King Kandaules was passionately in love with his wife and considered her the most beautiful of all women. He praised her beauty to one of his lancemen, Gyges, whom he treated as a friend and confidant. Finally he insisted that Gyges should see her naked; only in this way would he be able to understand the truth of Kandaules' claim. In spite of Gyges' protestations against this immodesty and violation of the queen's privacy, Kandaules left Gyges no choice but to do as he, the king, wished. The scheme designed by Kandaules involved Gyges being hidden in the royal bedchamber. He thus had a good view of the queen as she undressed. Then, as instructed, while the queen went towards the bed, Gyges slipped from the room. But she saw him and was deeply ashamed: nudity was unacceptable to the Lydians. Because the queen realized that her husband must have connived at Gyges' presence, she did not raise the alarm but plotted her vengeance in secret. The next day she summoned the unsuspecting Gyges and confronted him with a blunt choice: either he had to kill Kandaules, marry her and become king of the Lydians, or he would have to be killed as punishment for so blind an obedience to Kandaules that it resulted in him having seen what he should not have seen.

Gyges chose the first alternative, albeit reluctantly. With a fine sense of drama and poetic justice the queen then had Gyges repeat the actions of the previous night. Hidden in the bedchamber again, this time armed with a dagger, Gyges killed Kandaules once the king had fallen asleep. Thus he acquired both the queen and the kingdom over which he would rule for forty years.

Herodotus tells the story with masterly concision. The excellence of his style in this passage and his mastery of the art of summary composition have been admired since antiquity (Page 1951:34; Stahl 1968:385 and references there). The whole account occupies no more than 64 lines. Yet the characterization and delineation of action are vivid. ${ }^{2}$ Noteworthy is that Kandaules is in love with his wife, but is not content unless his good fortune in having a prodigiously beautiful woman as his wife is acknowledged and admired. Only by displaying his luck can he enjoy it fully. He thus turns the reluctant Gyges into a voyeur, but in the process engineers his own downfall. That this is somehow fated is suggested by the expression $x \rho \hat{\eta} \nu \gamma \dot{\alpha} \rho$

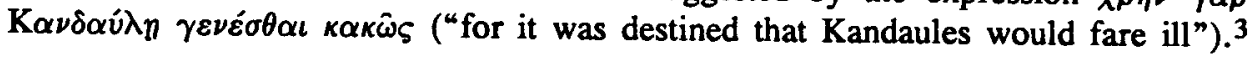

2 See Stahl 1968:389-397 for a perceptive analysis of the style of this passage.

3 All translations quoted in this paper are my own. 
The queen in Herodotus is anonymous but her decisive action creates some personality for the unnamed woman who brings swift retribution to her husband for scorning her personal dignity. These elements-Kandaules' psychological weakness, the queen's presence of mind, the idea of Kandaules' end as fated-all reappear in transpositions of the 'hypotexte'.

Less than a century after Herodotus composed his Historiae, Plato introduces a man called Gyges into his Republic. Here Gyges is a shepherd who accidentally discovers a golden ring when he descends into an opening in the ground caused by an earthquake. This ring is on the finger of a corpse in the interior of a hollow bronze horse. Gyges removes the ring and subsequently finds out that it has magical properties: it renders the wearer invisible if its bezel is turned to the inside. Gyges makes use of this property to seduce the king's wife, and with her co-operation he kills the king and takes over his throne. Neither the king nor the queen is named in Plato's account.

It was first thought that the name Gyges referred to two different individuals, but when one examines the common motifs of Gyges being hidden or unseen, and of the supplanting of the king as husband and monarch, it becomes clear that both stories are traditional versions of the same event-the overthrow of the Heraclid 'kings of Lydia. Plato's reason for relating the Gyges episode is, however, totally different from that of Herodotus. While Herodotus' point of departure is history, Plato's is illustration. Plato has Glaucon introduce the story to show that if a just man and an unjust man are both given the freedom to do as they please, undetected, the just man will be caught in the same pursuits as the unjust-in other words, individuals are ultimately led by self-interest. The most striking feature in the behaviour of Plato's Gyges is thus that he does not hesitate to act in his own interest. This contrasts with the reluctance and hesitancy with which Herodotus' Gyges reacts, first to Kandaules' proposal and then to the queen's ultimatum. The prime mover or instigator of the change of government, albeit unwittingly, in the Historiae is Kandaules; this has led some to see him as a tragic figure (Page 1951:27; Stahl 1968:393, 399).

Scholars have conjectured that drama may have been among the sources of Herodotus for his history of Lydia (Burn 1972:25). In 1950 a papyrus fragment was published which contained a page of iambic dialogue from a portrayal of the conspiracy of Gyges which conforms closely to Herodotus' narrative in I.8ff. However, no conclusive evidence has been presented as to whether this drama antedates Herodotus. D.L. Page (1951:21ff.) cautiously supports an early date but makes it clear that without further evidence there cannot be a definite answer. It may be a later attempt to dramatize Herodotus' account, which in itself contains good material for a drama. K. Latte (1950:141) believes that the fragment forms part of a drama from the post-Euripidean period.

While the existence of early Greek plays based on the story of Gyges and preceding Herodotus' account remains in doubt, there are at least two more modern European dramas dealing with this material: Friedrich Hebbel's Gyges und sein Ring (1856) and André Gide's Le Roi Candaule (1900). In addition there is the narrative 
in verse by Jean La Fontaine, Le Roi Candaule et le maitre en droit (1674), the prose tale by Théophile Gautier, Le Roi Candaule (1844), and the fresco of Gyges and Candaules by the seventeenth-century Venetian painter, Tiepolo, which figures prominently in Temporary Kings (1973), the eleventh volume of Anthony Powell's magnificent twelve-novel sequence called $A$ Dance to the Music of Time. The 'hypertextes' of the story of Gyges and Kandaules all derive from the 'hypotextes' of Herodotus and Plato, while occasional allusions to other ancient sources are probable. Each of the later works in its own way reflects the preoccupations of the respective authors and reveals aspects of the cultural ambience of the different countries and periods in which they were created. According to Genette, (1982:417) there is no 'innocent' transposition of a 'hypotexte'. Each author who adapts it has another theme in mind and each new treatment will add significance to the 'hypotexte'.

The earliest of the modern treatments of the story, that of La Fontaine, focuses on an aspect of the account which is by no means emphasized by Herodotus: the suggestive or even bawdy nature of the whole Kandaules-Gyges episode. Unlike his better known Fables, which have a moral purpose, La Fontaine's Contes are without instructive intent. Their main aim was to amuse his sophisticated contemporaries in Paris (Bassy 1982:14) with his witty depiction of ambiguous situations. La Fontaine thus manipulates the 'hypotexte' of Herodotus in a playful way to a purely artistic end. The combination of this story with that of the Master of Law, based on an original of 1558 by the Italian Giovanni Fiorentino (La Fontaine 1982:840 n.1), develops each of the tales in a new way and presents love's follies in a mildly lewd frame for the delight of the reader. In the preface to the first part of his Contes La Fontaine quotes from the prologue to the Andria of Terence to express his goal: "populo ut placerent quas fecisset fabulas".

La Fontaine chose rhyming verse for these tales as he regarded such a mode of narrative as livelier than prose. His choice therefore entailed what Genette (1982:323) calls 'transmodalisation', i.e. transposing a story from one literary genre to another (1982:323), and of course also translation.

Le Roi Candaule et le Maître en Droit is launched with this brief introduction:

Force gens ont été l'instrument de leur mal,

Candaule en est un témoignage.

(Many people have caused their own downfall:

Candaule is an example of this.)

Candaule's hapless personality is further delineated in the next line: "Ce roi fut en sottise un très grand personnage". This railing mock-epic tone of "greatness in stupidity' is maintained throughout. La Fontaine's Candaule wants to do his favourite vassal Gygès a special favour: he invites him to watch his wife in her bath so that he may enjoy her beauty. The only proviso attached is that Gygès' admiration should be confined to that suitable for a work of art and that he should on no account fall in love with her. Gygès is thus constrained to conceal the overwhelming passion which the sight of the queen's astonishing beauty evokes in 
him. The queen, however, notices his tender feelings for her and when Candaule foolishly recounts the whole voyeuristic episode to her, she hides her fury and secretly plans revenge. La Fontaine suggests that, in addition to shame and wrath, love may also have been one of the queen's motives, for Gyges was very handsome (and thus, one presumes, easy to forgive!). In the Contes of La Fontaine it is the husband's lot to be betrayed and abandoned. (The suggestion that the queen returns Gyges' love may derive from Plato's version, where she co-operates with Gyges in the slaying of her husband, but this is probably a coincidence arising from the interpretation of the facts of the narrative. There is no other indication that La Fontaine made use of the Platonic 'hypotexte'.) Without more ado, Gygès and the queen become lovers and despatch the cuckolded Candaule to the Underworld by poisoning his drink. Gygès then ascends the throne and thus the story is brought to a conclusion comparable to that of Herodotus, although some of the details have been altered. La Fontaine, however, by adding the second half of the tale which deals with the Master of Law hints that this is a typical incident from the battle between the sexes. This innovation arises from La Fontaine's altered purpose.

The second part of La Fontaine's tale is set in contemporary Rome where an eminent lawyer's counsel to his French pupil to go in search of amorous adventure actually results in the latter establishing a liaison with the wife of the former. When the young lover recounts the details of his mistress's appearance and behaviour, the older man is horrified to discover that the woman is none other than his own wife. His attempt to take the place of the lover at a rendezvous with his wife ends in public disgrace when her servant recognizes him and tricks him into being pushed naked into a room at the Law School. He is classified as mad and his marriage annulled. The lawyer thus, like Candaule, causes his own downfall by trying to initiate a protégé into a lewd adventure. La Fontaine's purpose in telling the story of Gyges and Kandaules is therefore to illustrate Love's folly in an entertaining way. Unlike Herodotus he is not interested in the historical validity of the events but rather in their potential as the ingredients of a good story.

The opening of the Conte of Theophile Gautier called Le Roi Candaule seems to reflect a strong concern for historical accuracy: "Cinq cents ans après la guerre de Troie, et sept cent quinze ans avant notre ère, c'était grande fête à Sardes.-Le roi Candaule se mariait". ("Five hundred years after the Trojan war and seven hundred and fifteen years before our era, there was great celebration in Sardis: King Candaule was getting married.") It soon becomes evident, however, that this attention to minute detail is characteristic of Gautier's style of narrative. It is not so much historical accuracy that he strives for as a complete and subtly nuanced portrayal of all aspects of the story of Gygès, Candaule and Nyssia. (This is the name Gautier gives to Candaule's bride; it probably stems from an account by Ptolemaeus Chennus in his New History which is considered to have been written in the late fifth century A.D. [Page 1951:19]. ${ }^{4}$ Certain other aspects of Gautier's Conte

$4 \quad$ In the narrative of $X$ anthos which is found in Nicolaus of Damascus, the name of Kandaules' queen is Toudo (Page 1951:18). The name Rhodope, used by Hebbel, seems to have been invented by him. 
may also be traced back to this 'hypotexte'-notably that Nyssia's eyes were believed to have double pupils and that she was extremely sharp-sighted because she possessed a dragon-stone!) Gautier's first concern in his works of literature was to create something of beauty. He was a member of the 'Parnassien' movement in France (Van Tieghem 1974:235-242) whose slogan of 'l'Art pour l'Art' expressed their belief that beauty was diametrically opposed to utility. Art should therefore have no social or political purpose; its virtue resides in the mysterious power of beauty to raise the soul of the reader/beholder. As their name indicates, the Parnassians found ancient Greece a rich source of inspiration. Gautier's works, prose as well as poetry, reflect this. His choice of the story of Gyges and Kandaules for one of his ancient tales is therefore not surprising. The eastern setting of the story, Sardis, gave Gautier the opportunity to create an extravagant oriental backdrop against which he could display his powers of narration and at the same time indulge his virtuosity in describing beautiful Greek works of art. His first description of the royal palace in Sardis already gives some indication of this: “... où l'élégance de l'architecture grecque se mêlait aux fantaisies et aux énormités du goût asiatique" ("... where the elegance of Greek architecture mingled with the fantasies and exaggerations of oriental taste").

Gautier's tale fills more than sixty pages, while La Fontaine needed only 132 lines for his version of the events of Gyges' succession to the throne of Lydia; the second part of his tale about the lawyer does not refer explicitly to the story of Gyges again. When the conciseness of the ancient 'hypotextes' is taken into account, it is apparent that both French writers, especially Gautier, considerably expanded the material of the 'hypotextes'. This procedure is designated as 'augmentation' by Genette (1982:321). Gautier consequently invented many aspects of his story and also made use of other ancient sources, notably Xanthos, for certain details (cf. Stahl 1968:386-388). There is no sign of Gautier's powers of invention flagging. On the contrary, he seems to revel in describing not only objects, as noted above, but also the physiognomy and sentiments of the characters.

Gautier starts his tale at an earlier point than Herodotus or Plato-before the marriage of Candaule. (This aspect also corresponds to Xanthos' account, which tells how Gyges was sent by the king to fetch his bride but on the way fell in love with her. The virtuous bride complained to her prospective husband, who vowed that he would execute Gyges on the next day. Gyges was however warned by a maid and during the night murdered the king (Page 1951:18) ). A plot of this kind allows Gautier to depict Nyssia's non-Greek background and especially the strict conventions governing her chastity. No part of her body, not even her face, is to be seen by anyone but her servants or her husband. In spite of this she enjoys the reputation of being a peerless beauty. The delineation of Nyssia's beauty lends itself particularly well to Gautier's aesthetics: for instance. he devotes almost two pages to the description of her eyes. The reader is thus allowed a privileged view of what was forbidden to Nyssia's contemporaries. Gygès is a handsome, adventurous and 
ambitious young man who has once had the good fortune to glimpse Nyssia's perfection when the wind blew her veil off her face for a moment. Moreover, he feels that their destinies are somehow joined.

Although Candaule has the physical stature and strength of a warrior, he is gentle and melancholic and more of a poet than a soldier, His main interest is in beautiful objects and he is a keen collector of fine art. ${ }^{5}$ In fact, he is somewhat eccentric: "[S]ans être tout à fait bizarre, [Candaule] semblait néanmoins difficilement appréciable au point de vue ordinaire" ("Candaule was not altogether bizarre, yet it seemed as if it would be difficult for an ordinary person to understand him") (Gautier 1844:48).

As a connoisseur of beauty Candaule delights in contemplating his bride's perfection. He finds pleasure in asking Nyssia to assume certain classical guises, Aphrodite or a Bacchante for instance, and then gazing at her in silence. This is repugnant to the queen, who is ferociously chaste and does not care for her own beauty. Her coldness only intensifies Candaules' passion for her as a perfect work of art. Consequently he asks her to lift her veil at a public feast so that others may share the joy of her beauty, but to Nyssia this would be outrageous immodesty. Unable to find full enjoyment in the possession of such beauty unless someone can share his admiration, Candaule persuades the reluctant Gygès to fall in with his scheme. Although considerably more detail is provided, this plan is essentially the same as in Herodotus. A curious aspect of Gautier's story is that it is mentioned quite early that Gygès has a ring which has the power to make him invisible (Gautier 1844:55), yet no further reference is made to the ring and it plays no part in the bedroom scene or murder.

To Gygès such a morally reprehensible situation is exacerbated by the husband's complicity. Yet, such is the effect of Nyssia's beauty that his moral outrage takes second place to admiration at the sight of Nyssia undressing. Gautier is so carried away that his description of this scenes covers three and a half pages. He has frequent recourse to comparison with goddesses, classical statuary, and the colour and texture of fine materials. As in Herodotus, the queen catches sight of Gygès as he slips away, and with the same comprehension of her husband's complicity she keeps quiet.

An innovation by Gautier is his attention to the effect of Nyssia's beauty on Gygès. The attraction which he previously felt for her is heightened to an overwhelming passion, of which one aspect is jealousy of Candaule. Gygès turns the favour Candaule has done him into an insult. The king wanted to vaunt his good fortune to one powerless to enjoy it. Gygès now hates Candaule. Nyssia's feelings for Candaule, which have never been very warm as their approaches to life were too

$5 \quad$ It is tempting to think that Gautier may have developed this aspect of Candaule from Pliny the Elder's mention of Kandaules' willingness to pay a particularly high price for a painting by Bularchus of the battle of Magnetes, as confirming the great value already put upon the art of painting in the seventh century B.C. (N.H. 35.34.2). 
divergent, have also turned to hatred. She feels dishonoured by adulterous eyes. Candaule has scorned her deepest wishes.

The story thus takes the same turning as in Herodotus, but to Gygès' choice between life and death are added complex motives of love for Nyssia, jealousy of and hatred for Candaule, and a feeling that fate has guided him to a chance of gaining Nyssia.

Gautier slips in and out of the role of omniscient narrator. At this point he poses a question, which is probably already in the mind of the reader as well, about Nyssia's true feelings. Did she reciprocate Gygès' ardour? The author avoids a definite answer by pleading the difficulty of determining such a nuance of feeling after so many centuries. He thus leaves the reader to decide. The outcome of the story seems to favour a positive answer as, after a brisk report of the events familiar from Herodotus, Gygès and Nyssia are said to have lived happily together as their attitudes to life were commensurate. Gygès shared Nyssia's determination that not even her face should be unveiled to anyone but her husband.

Like $\mathrm{La}$ Fontaine, Gautier is primarily interested in narrating the story from a new perspective, but while $\mathrm{La}$ Fontaine concentrates on the aspects relating to the wars between the sexes in a light-hearted way, Gautier's goal is to recreate for the reader the visual opulence and splendour of the court of Lydia at Sardis. Instead of becoming merely another beautiful object in Candaule's collection, Nyssia has her own standards by which she lives and to which Gygès also subscribes. The way in which Gautier has treated the story seems to imply that mere outward appreciation of beauty is not enough; attention should also be paid to inward aspects, to the thoughts and feelings which distinguish humans from inanimate objects. Without due respect to these, human relationships become arid and lifeless.

Yet another interpretation of the material provided by the 'hypotextes' is found in a drama of Friedrich Hebbel. The German playwright had no ancient drama to serve as example. Indeed, according to the testimony of his letters (Rees 1930:150; Meetz 1962:73; Schaub 1972:71), the idea of writing a drama around the story of Gyges and Kandaules was given to Hebbel by a minor civil servant. Hebbel then read up the story, previously unknown to him, in Pierer's Lexicon, which directed him to the ancient sources, Herodotus and Plato (Schaub 1972:71). As P.J. Conradie has rightly observed (1963:26) with reference to modern dramas based on ancient myths:

When a modern dramatist chooses for his plot a myth which has not been dramatised by an ancient poet, he has greater freedom in his treatment of it. He has only the bare outline of the story to go upon and has to invent practically the whole plot in which he gives dramatic form to the story. In his interpretation of the myth, too, he has greater freedom.

In my view these observations apply mutatis mutandis to the material from which Hebbel created Gyges und sein Ring in 1856. According to Genette's theory the transposition from prose narrative into drama is another example of 'transmodalisation'. Hebbel's play takes it outline from the Historiae, but, as is to 
be expected from the title, Gyges und sein Ring, Plato's version also provides considerable material: Gyges' occupation as shepherd and his possession of a magic ring. The most important legacy from Plato is perhaps the more dominant role played by Gyges. Hebbel himself seems to have invented the name Rhodope for the queen and a number of minor characters, amongst them a slave woman called Lesbia.

Hebbel's Kandaules is a ruler who has outgrown the spirit of his time. He wants to be accepted as king on his own merits and not by virtue of his ancestry:

\section{Hier gilt der König}

Nur seiner Krone wegen und die Krone

Des Rostes wegen. Weh' dem der sie scheuert, Je blanker, um so leichter an Gewicht.

(Here the King has power

Only because of his crown, and the crown

Because of rust. Woe to him who scours it:

The brighter it is, the less will it weigh!)

The situation is complicated by two factors: political dissatisfaction amongst the Lydians with Kandaules' disregard for tradition, and the great popularity of the Greek guest, Gyges, owing to his feats of prowess at the feast of Hercules. At this feast Gyges is attracted to Lesbia, the queen's maid. When he confides his attraction to Kandaules, the king boasts about the superior beauty of his consort. This leads to the bedroom scene where Gyges remains invisible through the use of his ring. Hebbel's Gyges is so powerfully affected by Rhodope's beauty that guilt at having polluted her by his disregard of the taboo on her being seen unveiled by a man other than her husband, makes him wish to end his life.

The queen, for her part, is drawn as a woman who respects tradition and would not consent to being seen unveiled. Because her point of view is clearly represented, as with Gautier's Nyssia, there is a sharper focus on the violation of the bond of mutual respect between the king and the queen.

The twists and turns of the play's plot are extremely intricate. The gist is that the queen, like some of her literary predecessors, eventually falls in love with Gyges. They share a respect for tradition, and horror at Kandaules' flouting of ancient customs. In keeping with his character as an honourable man, Gyges refuses to kill his friend and king, but agrees to a duel. The winner will be Rhodope's husband and none but her husband will have seen her. True to the 'hypotexte', Gyges predictably, but with the duel providing an element of suspense, emerges as victor. He marries Rhodope; the ring is buried with Kandaules. But the play ends with a surprise-Rhodope commits suicide. Although outward form has been restored, she feels that she has lost her purity.

Contradictions within the personalities of the three main characters mar the success of Hebbel's conception, but he does raise some interesting points about tradition versus reform and about the risks of overhasty change which disregards deeply held beliefs. A notable feature of Hebbel's play is his treatment of the 
queen's character. Whereas Herodotus' queen asserts her rights as an individual by decisive action, Hebbel attempts a more complicated portrayal of female psychology which owes much to the heroines of classical tragedy.

In the preface to Le Roi Candaule, which followed nearly half a century later, André Gide aligns himself closely with Gautier's approach to literature as a work of art. Although Gide's work is a drama there are other echoes, besides the title, of Gautier's prose tale. Gide is well known for his adaptation of Greek myths and undoubtedly knew the 'hypotextes' of both Herodotus and Plato. There is no evidence that he was aware of Hebbel's play on the same subject. His transposition of the earlier prose works into drama must therefore be regarded as his own inspiration. In addition to certain alterations to the story, Gyges is reduced to a humble fisherman who, despite years of separation from his childhood playmate, Candaule, still has warm feelings for the king. Gide's most fundamental change, however, is in his overall conception of the piece as dealing with human happiness. He develops to an extreme the trait discernible in Herodotus' king-the need for his good fortune to be acknowledged by others. While in his cups Candaule admits:
Mon bonheur semble
Puiser sa force et sa violence en autrui
Il me semble parfois qu'il n'existe
Que dans la connaissance qu'en ont les autres
Et que je ne possède
Que lorsqu'on me sait posséder.
(It seems that my happiness
derives its strength from others.
Sometimes it looks as if
it exists solely in the ackowledgement by others
and that I possess nothing unless others
have knowledge of it.)

This is clearly a much expanded and generalized version of Herodotus' portrayal of Kandaules' need for the beauty of his wife to be admired. Gide's plot is driven by the king's dual quest: to find a true friend, and to find happiness by making others happy.

The play opens with a banquet to which Candaule has invited all his courtiers and where his beautiful wife, Nyssia, is present, unveiled for the first time. The king wants everyone to experience the joy of seeing her beauty. Inside a fish served

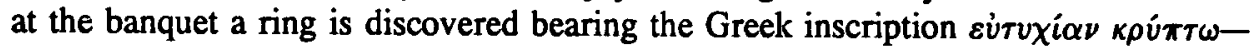
"I conceal happiness". The fish has been bought from Gygès, who is summoned to the king. Although Gygès is at the opposite end of the scale to the king as far as position and wealth go, he is more fortunate than his erstwhile friend because he has something which the king lacks-control of his own life. Candaule sees Gygès as a worthy recipient of his friendship but Gygès makes it clear that a mere showering of material goods cannot establish friendship. The king conceives the idea of sharing his most precious and beautiful possession, his wife, with Gygès. This is facilitated 
by the special property of invisibility bestowed by the ring which Candaule gives to Gygès. Gygès then spends a night of love with the queen, who thinks her husband is in unusually high spirits.

Throughout the play the queen and Gygès emphasize that happiness must be kept secret if it is to endure. This is in sharp opposition to Candaule's approach to life.

The plot, after various twists, ends again in Candaule being killed and Gygès proclaimed husband and king. Significantly his first action is to veil Nyssia again. Gygès is determined to restore her to the position of hidden intimacy from which Candaule had wrested her. The play thus has the same ending as Gautier's tale but the characters do not strive after the same purity as in Gyges und sein Ring.

Critics have interpreted this play in many divergent ways. J.C. McLaren (quoted by Watson-Williams [1967:81-82]), for instance, explains it thus: "The defeat of Candaule by Gygès does not symbolize the political conquest of capitalism by a communist proletariat. It represents, rather, the defeat of abstraction and illusion by reality." Brée (Watson-Williams 1967:82) offers a psychological interpretation, namely that the play reflects a homosexual obsession.

This diversity of interpretation runs counter to Gide's declaration in his preface to the first edition of the play: "J'ai voulu faire oeuvre d'art, simplement" ("I simply wanted to create a work of art"). Exasperated by the inability of critics to accept the play at its face value, Gide attached a selection of press cuttings containing widely divergent interpretations of Le Roi Candaule as preface to the second edition, enjoining readers to form their own opinions.

After this drama Gide abandoned writing for the theatre for thirty years. Later critics, however, did not neglect to add their views on Le Roi Candaule. Thus Gilbert Highet (1967:526) seeks to link Le Roi Candaule to Oscar Wilde's Salomé. He characterizes both plays as the dramatization of "an oriental story from the fringes of the Greek world, in a style of classical restraint", but then adds: "Both plays deal with sinister distortions of sexual passion, and both authors have added a still more sinister twist to the original plot." In the phrase "sinister distortions of sexual passion" Highet is probably referring to the king's desire to exhibit his wife. But Highet himself is perhaps guilty of a 'sinister distortion' of critical objectivity when he further remarks: "André Gide stands apart ... as an inventor of repulsive new episodes and vicious motives ... Gide makes the king, in a phenomenal access of generosity, leave the room and tell Gygès to substitute for him that night" (1967:536). It is clear that Highet does not like Gide's version of Herodotus' story which he finds "spicy enough", but he fails to understand the reason for Candaule's behaviour in Gide's play.

The issue at the heart of the story in its different versions is why Kandaules should have the need to exhibit his wife to his confidant. Herodotus' motivation seems relatively straightforward: the king requires outside confirmation that her beauty is as overwhelming as he finds it. This points to weakness and lack of selfconfidence rather than deviation. La Fontaine treats the theme as a titillating anecdote: Candaule is made to seem silly rather than abnormal. Thus La Fontaine's 
Conte may almost be termed a parody of the story told by Herodotus. Gautier's Candaule treats his queen as an asexual object: she is merely another precious item added to his collection. The fact that she cannot be exhibited like the others causes him such chagrin that he invites Gygès as spectator rather than as voyeur. While La Fontaine's king warns Gygès beforehand that he is not to fall in love with the queen, Gautier's king issues a similar warning only after the event-as if it has occurred to him as an afterthought that Gygès might respond as a man rather than simply as a lover of beauty. In Gide's play Candaule's sharing of Nyssia with Gygès is rooted in the king's desire to make his friend happy. The outcome of the play shows that Candaule's approach to life is wrong: he pays for it with his life. Gide, therefore, can hardly be accused of supporting this behaviour. An interpretation of the kingqueen-Gyges triangle which is far more explicitly grounded in the pscyhology of sexual deviance (without necessarily propagating it!) is that offered in the most recent literary treatment this paper will consider. This is the portrayal of the story in the novel sequence $A$ Dance to the Music of Time by Anthony Powell.

Powell introduces the story of Gyges and Candaules in the eleventh volume of $A$ Dance to the Music of Time. In the course of the novel sequence characters appear and disappear as in the course of life people meet, are sometimes frequently thrown together for a while, and then lose touch, only to encounter one another again in different circumstances after a longer or shorter interval. The entire narrative is presented to the reader from the perspective of Nicholas Jenkins, a writer and former publisher whose interests include painting and the history of art. The events of the novel sequence span most of the twentieth century-from the narrator's schooldays before, during and after the First World War, to the early 1970's. Temporary Kings, the eleventh volume, opens with a cultural conference in Venice in 1958 to which Nicholas Jenkins is a delegate. One of the entertainments provided for the conference-goers is a visit to the Bragadin Palazzo. One room of this privately owned Palazzo is decorated with a fresco of Candaules and Gyges by the celebrated eighteenth-century Venetian painter Gianbattista Tiepolo. There is no doubt that Tiepolo actually existed and that he actually painted numerous frescoes in palazzi, some in Venice. Many of his paintings are on themes from Classical mythology or ancient history (Morassi 1962). Furthermore, Powell's description of the fresco is so realistic that one could assume that he is describing a real painting:

Miraculous volumes of colour billowed, gleamed, vibrated, above us ... The scene above was enigmatic. A group of three main figures occupied respectively foreground, middle distance, background, all linked together by some intensely dramatic situation. These persons stood in a pillared room, spacious, though apparently no more than a bedchamber, which had unexpectedly managed to float out of whatever building it was normally partsome palace, one imagined-to remain suspended, a kind of celestial 'Mulberry' set for action in the upper reaches of the sky. The skill of the painter brought complete conviction to the phenomena round about ... A cloaked and helmeted personage was slipping swiftly, unostentatiously, away 
from the room towards a curtained doorway ... At that end of the sky, an ominous storm was plainly brewing up, dark clouds already shot with coruscations of lightning and tongues of flame (as if an air-raid were in progress), their glare revealing, in the shadows of the bedchamber, an alcove where this tall onlooker had undoubtedly lurked a moment beforehand. Whether or not the lady was categorically aware of an intruding presence threatening the privacy of sexual embrace, whether her suspicions had been only partially aroused, was undetermined ... The calmly classical treatment of the scene, breathtaking in opulence of shapes and colours, imposed at the same time a sense of awful tension, imminent tragedy not long to be delayed. (Powell 1973:82, 89, 91-92)

The impression of the actual existence of this painting is enhanced by it being described as not open to the public and never having been photographed, and by remarks Powell puts into the mouth of one of the delegates to the conference, Dr. Emily Brightman, "a lady don from Oxford", who links Candaules and Gyges to other well known and authentic works of Tiepolo:

[O]ne is a little reminded of Iphigenia in the Villa Valmarana, or the Mars and Venus there. The usual consummate skill in handling aerial perspectives. The wife of Candaules-Gautier calls her Nyssia, but I suspect the name invented by him-is obviously the same model as Pharaoh's daughter in Moses saved from the water at Edinburgh, also the lady in all the Antony and Cleopatra sequences, such as those at the Labia Palace, which I was once lucky enough to see. (Powell 1973:83)

Later Dr. Brightman muses: "I wonder whether the model was the painter's wife ... She occurs so often in his pictures. I must look into that. If so, she was Guardi's sister. Gyges looks rather like the soldier in The Agony in the Garden, who so much resembles General Rommel" (Powell 1973:92). An examination of the catalogue of Tiepolo's works shows, however, that no Candaules and Gyges by the Venetian master exists. This fresco is created in the mind of the reader through the words Powell transmits via the narrator Nicholas Jenkins.

Powell's autobiography, To Keep the Ball Rolling, sheds some light on the genesis of this incident in the novel. In the fourth volume, The Strangers are All Gone (Powell 1982:168), he describes a cultural conference he attended in Venice in 1958: "In the event the occasion was thoroughly enjoyable; incidentally providing a background (much adapted) for some of the scenes in Temporary Kings (1973)." More specifically relevant to Tiepolo is the mention of an evening spent at "the Palazzo Labia, a setting which was to provide in literary terms for Temporary Kings what is called in music and painting a capriccio; the painting sense being the one that I have in mind". Powell (1982:170) adds that his host at the Palazzo Labia "showed me the magnificent frescoes in the Palace executed by Gianbattista Tiepolo". These (authentic and authenticated!) frescoes depict The Meeting of Antony and Cleopatra, and The Banquet of Antony and Cleopatra (cf. Morassi 1962:59). 
Powell has thus transmuted his own experience into an episode, a capriccio, in his novel. By means of a complex yet subtle application of the story of Candaules and Gyges, Powell psychologically illuminates two of the main characters of $A$ Dance to the Music of Time. Appropriately enough, as the conference goers are admiring the Tiepolo, the two characters in question appear, Lord Widmerpool and his beautiful wife, Pamela. They are house guests in the palace. Kenneth Widmerpool must rank as one of the most memorable characters of twentiethcentury fiction. His and Nicholas Jenkins' paths have crossed at intervals since they were at school together. Although reasonably cordial relations have always been maintained they could not really be described as friends because their views on life differ too fundamentally. Widmerpool develops from a most unattractive, not particularly gifted and rather ludricous schoolboy in the first of the novels, $A$ Question of Upbringing, into a powerful figure in the world of finance and of politics through sheer, dogged persistence and ruthlessness. Only in love does he remain remarkably unsuccessful until he manages, rather surprisingly, to marry Pamela Flitton, a notorious and haughty beauty. This marriage causes much speculation amongst the other characters in the novels. Why should the much sought-after Pamela marry, and stay married, to Widmerpool, who had several times in the end been rejected by less eligible fiancées than Pamela? The answer to this question is provided by means of the capriccio of the Candaules and Gyges fresco.

Pamela is extraordinarily interested in the fresco which depicts the scene in the bedchamber as described by Herodotus at the moment when the king is waiting in bed, the queen has undressed and is on her way to bed, and Gyges is trying to slip undetected from the room. In other words, it is the moment of crisis in the story when the queen notices Gyges. Pamela's interest in the fresco leads to a thorough explanation of the historical background by Dr. Emily Brightman. She refers to Herodotus, Gautier and Gide, and the variant of the succession story in Plato is also mentioned. This is Powell's technique of providing readers with the requisite scholarly information in an acceptable way. As Fuhrmann (1971:142) remarks about classical sources, later writers often want to show that they are 'quoting' an earlier version. Powell goes as far as having Dr. Brightman correct the information she gives in Temporary Kings, namely that Gautier invented the name Nyssia for Candaules' wife, by her communicating additional facts about the name she has subsequently gleaned from ancient authorities. This episode appears in the final volume, Hearing Secret Harmonies (Powell 1975:55-56), when Jenkins meets Dr. Brightman again.

Pamela's interpretation of the scene depicted in the fresco differs from the conventional in that she believes the king's exhibitionism went futher than displaying the nudity of his wife: "What the king wanted was to be watched screwing." The reason for her interpretation stems from the relationship in the Widmerpool marriage. Widmerpool is a voyeur who obtains sexual gratification by watching his wife's liaisons with different men, while she enjoys being put on show. The introduction of the fresco at this point in the novel refers especially to rumours that a recently deceased French intellectual, Ferrand-Sénéschal, died while in bed with 
Pamela, Widmerpool witnessing the encounter as voyeur. Powell himself must have felt that there were certain difficulties in the application of the story to the characters in the novel, for later in Temporary Kings Jenkins recounts the incident in Venice to his friend Hugo Moreland:

Candaules can obviously be better paralleled than Gyges. Most men have a bit of Candaules in them. Your friend Widmerpool seems to have quite a lot, if he really liked exhibiting his wife. She was the Queen all right, if she's to be believed as being put on show. Also, in knowing that, herself intended to kill the King. Not necessarily physical killing, but revenge. Who was Gyges?

Hardly Ferrand-Sénéschal. In any case, through no fault of his own, he failed in that rôle. Others seemed to have enjoyed his Gyges-like privileges without dethroning the King. Candaules-Widmerpool continues to reign.

No, it doesn't really work, said Moreland. All the same, it's a splendid fable of Love and Friendship-what you're liable to get from both-but the bearings are more general than particular, in spite of certain striking resemblances in this case. (Powell 1973:273-274)

In spite of the difficulty of assigning roles from the Candaules fresco which precisely correspond to the characters in the Widmerpool ménage, this painting plays a crucial part in the destruction of Widmerpool and Pamela. She destroys him politically by publicly taunting him with his voyeurism and his political betrayal of Ferrand-Séneschal, and she herself commits suicide a year later.

Powell thus makes use of the Kandaules and Gyges story in a transposed format double remove-in order to elucidate the habits of two of the main characters in $A$ Dance to the Music of Time. The outcome of the story is not the traditional one, but such a straightforward linear narrative would not slot easily into the complex structure of Powell's novels which, according to Hilary Spurling (1977:xi), demonstrates "the heresy of naturalism":

a structure so contrived that, as it flows, straggles or jerks itself along, by turns farcical and grim, sombre, tumultuous, absurd, reaching out through almost infinite varieties of egotism to embrace the furthest shores of crankiness and melancholia, it seems not so much to shape as to contain the disorderly process of life itself. It is not for nothing that Nicholas Jenkins takes his first name from that specialist in rhythm and design, Nicolas Poussin, 6 whose painting provides both the title and the model for $A$ Dance to the Music of Time.

6 The picture, A Dance to the Music of Time, by the seventeenth-century French painter Nicolas Poussin is in the Wallace Collection in London. Powell's novel sequence takes its title from this work. Allusions to the painting in the first, A Question of Upbringing, and last, Hearing Secret Harmonies, of the sequence not only underscore Powell's central theme, but effectively links the whole series to his interpretation of Poussin's painting. For a detailed analysis of the picture and the history of subsequent reactions to it see Beresford 1995. 
Powell's treatment of the story of Gyges and Kandaules takes the art of creating something new from old material ('faire du neuf avec du vieux'-Genette 1982:556) to new heights. He brings into his novel not only Herodotus and Plato, but also Gautier and Gide; to the rich layers of European literary tradition he adds that of painting. As Genette observes, this method has the advantage of producing something which is more complex and savoury than a work which has been made from scratch ("exprès"). The new function superimposed upon the old intermingles with it, and the harmony and dissonance between the different elements give flavour to the whole. Although, as Genette maintains, this is often a kind of game, and Powell's playful treatment makes it seem so (albeit a game of a very sophisticated kind!), the example of the various ways in which the different authors have manipulated the story of Gyges and Kandaules proves the interrelationship of the arts, and the vitality of the Greco-Roman tradition in Western culture.

\section{BIBLIOGRAPHY}

Bassy, A-M 1982. Preface to La Fontaine: Contes et nouvelles en vers. Paris: Gallimard.

Beresford, R 1995. 'A Dance to the Music of Time' by Nicolas Poussin. London: The Wallace Collection.

Burn, A R 1972. Introduction to Herodotus: The Histories. Harmondsworth: Penguin.

Conradie, P J 1963. The Treatment of Greek Myths in Modern French Drama: A Study of the 'Classical' plays of Anouilh, Cocteau, Giraudoux and Sartre. Annale van die Universiteit van Stellenbosch Vol. 29 Series B no. 2.

Conradie, P J 1976. Iphigeneia, of die veelduidigheid van die mite. In: Niks is in sy tyd gesluit: Opstelle oor klassieke en moderne drama. Pretoria \& Kaapstad: Academia.

Fuhrmann, M 1971. Mythos als Wiederholung in der griechischen Tragödie und im Drama des 20. Jahrhunderts. In: Fuhrmann, M (Hrsg.), Terror und Spiel: Probleme der Mythenrezeption, 121-143. München: Wilhelm Fink.

La Fontaine, J 1982. Contes et nouvelles en vers, éd. A-M Bassy. Paris: Gallimard.

La Fontaine, J 1934. Fables choisies, éd. Cait \& Famin. Paris: Larousse. (Livres 1 à 6).

Gautier, T [1844] 1963. Le Roman de la Momie précédé de trois contes antiques: Une Nuit de Cléopâtre; Le Roi Candaule; Arria Marcella, èd. A Boschot. Paris: Garnier.

Genette, G 1982. Palimpsestes: La littérature au second degré. Paris: Seuil.

Gide, A 1947. Thêâtre: Saul; Le Roi Candaule; CEdipe; Perséphone; Le treizième Arbre. Paris: Gallimard.

Gould, J 1989. Herodotus. London: Weidenfeld \& Nicholson.

Hebbel, F 1856. Gyges und sein Ring, in: Sämmtliche Werke, hrsg. R M Werner, Bd. 3, 237-344. Berlin: Behr's Verlag. 
Herodotus. 1972. The Histories. Translated by A De Sélincourt; revised with an introduction and notes by A R Burn. Harmondsworth: Penguin.

Highet, G 1967. The Classical Tradition: Greek and Roman Influences on Western Literature. Oxford: Oxford University Press.

Latte, K 1950. Ein antikes Gygesdrama. Eranos 48, 137-141.

Meetz, A 1962. Friedrich Hebbel. Stuttgart: J B Metzlersche Verlagsbuchhandlung.

Morassi, A 1962. A Complete Catalogue of the Paintings of G.B. Tiepolo Including Pictures by his Pupils and Followers Wrongly Attributed to Him. London: Phaidon Press.

Page, D L 1951. A New Chapter in the History of Greek Tragedy. Cambridge: Cambridge University Press.

Powell, A 1951. A Question of Upbringing. Glasgow: Fontana.

Powell, A 1973. Temporary Kings. Glasgow: Fontana.

Powell, A 1975. Hearing Secret Harmonies. Glasgow: Fontana.

Powell, A 1982. To Keep the Ball Rolling: The Memoirs of Anthomy Powell. Vol. 4: The Strangers are All Gone. London: Heinemann.

Rees, G B 1930. Friedrich Hebbel as a Dramatic Artist: A Study of his Dramatic Theory and of Its Relationship to His Dramas. London: G. Bell.

Schaub, M 1972. Friedrich Hebbel. Velber bei Hannover: Friedrich Verlag.

Smith, K F 1902. The Tale of Gyges and the King of Lydia. American Journal of Philology 23, 261-282.

Spurling, H 1977. Handbook to Anthony Powell's 'Music of Time'. London: Heinemann.

Stahl, H P 1968. Herodots Gyges-Tragödie. Hermes 96, 385-400.

Steiner, G 1984. Antigones. Oxford: Oxford University Press.

Van Tieghem, P 1974. Les grandes doctrines littéraires en France de la Pléiade au Surréalisme. Paris: Presses Universitaires de France.

Watson-Williams, H 1967. André Gide and the Greek Myth. Oxford: Clarendon Press. 